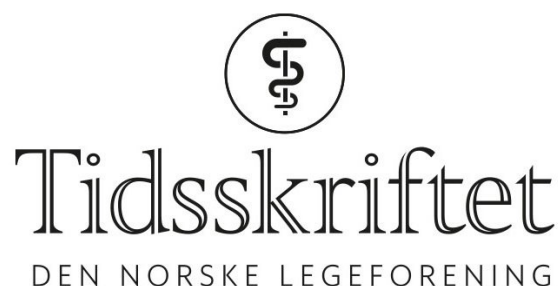

\title{
Et spedbarn med kul på halsen
}

RETTELSE

SVERRE MORTEN ZAHL

E-post: sverre.morten.zahl@helse-mr.no

CAMILLA JØSOK NYBØ

KAREN REISTAD SALBERG

Tidsskr Nor Legeforen 2018: 138: 657

I Tidsskriftet nr. 7/2018 s. 657 skal det i siste avsnitt, linje 6, stå: histologibildet.

Vi beklager feilen, den er rettet på nett.

Publisert: 25. april 2018. Tidsskr Nor Legeforen. DOI: 10.4045/tidsskr.18.0342

(ㅇ) Tidsskrift for Den norske legeforening 2020. Lastet ned fra tidsskriftet.no 